\title{
MORPHOMETRIC ASPECTS OF GROWTH AND VARIATION IN AN ASSEMBL.AGE OF SILURIAN TRILOBITES
}

HUGHES*. Nigel C.. Geier Collections and Research Center, Cincinnati Museum of Natural History. 1720 Gilbert Avenue, Cincinnati, OH 45202; CHAPMAN, Ralph. E. Applied Morphometrics Laboratory, ADP NHB MRC 136. Smithsonian Institution, Washington. D.C. 20560.

The tuffaceous Homerian (Upper Wenlock) "Aulacopleura Shale" from $\mathrm{Na}$ Cernidlech Hill, Lodænice, Czech Republic contains 11 common trilobite species belonging to a wide variety of clades. The majority of post-Cambrian trilobite morphotypes are represented by well-preserved, complete specimens. This situation provides a unique opportunity to compare patterns of growth across a broad range of trilobites, normalized for preservational style and taphomomic condition.

Analyses of morphologic landmarks and multivariate relationships among metric distances of the proetide Aulacopleura konincki show that morphologic variabilty of overall shape is approximately constant from early meraspis onwards, increasing slightly in the holaspid growth phase. Addition of segments to the thorax progressed steadily throughout meraspis, but the rate slackened at a point in ontogeny marked by a sharp change in the growth trajectory of the pygidium. This transition is analagous to the meraspis-holaspis transition in other trilobites. A. konincki, unlike any other described trilobite, continued to add segments to the thorax throughout holaspid growth, and holaspid specimens may contain a range of 5 segments, with between $18-22$ thoracic tergites. Variability of segment number in holaspis is significantly greater than in meraspis.

Morphological variabilty in shape and segment numbers of the odontopleuride Odontopleura ovata is approximately constant throughout growth, and the meraspid phases of both $O$. ovata and $A$. konincki share a common growth trajectory. Both taxa attained 9 thoracic segments at the same cephalic length (@1.0 mm), but $O$. ovata ceased segment production at that point. While holaspids of $O$. ovata have cephalic lengths between 1.0 and $9.8 \mathrm{~mm}$, all specimens show 9 thoracic segments. A similar pattern of constancy of thoracic segment numbers in holaspis is seen in other common Lodenice trilobites, including the proetide Scharyia wenlockia (6 segments), cheirurid Cheirurus insignis (11 segments), phacopid Phacopidella glocheri (11 segments), scutelluid Planiscutellum planum (10 segments), and lichide Dicranopeltis scabra (11 segments). Morphometric analyses of the shapes of these taxa do not indicate striking differences in variability among species.

These results suggest the following: 1) meraspid growth trajectories are similar in trilobite clades with widely different holaspid segment numbers; 2) overall body proportions appear to be more tightly constrained than segment numbers, supporting the size-equilibrium model of arthropod growth: 3) high variability in holaspid segment numbers in $A$. konincki is likely related to its unique morphology, rather than an environmental control affecting all trilobites: 4 ) this variability may be a function of high segment numbers, as this attribute distinguishes $A$. konincki from the other taxa.

Variability of holaspid segment numbers is commonly reported in Cambrian trilobites, and may be a function of the large numbers of thoracic segments that characterize pleisiomorphic trilobite taxa. A. konincki is an advanced homeomorph of Cambrian trilobites, suggesting that ecologic. rather than genetic. constraints may determine patterns of intraspecific variation in holaspid thoracic segment numbers. 